\title{
SUPPORTING NOVICE TEACHERS THROUGH MENTORING AND INDUCTION IN THE UNITED STATES
}

\begin{abstract}
The study focuses on the U.S. system of novice teacher support. The study highlights the evolution of mentoring from a traditional, isolated, hierarchical one-to-one relationship to multiple interactions which comprise a collaborative developmental network. The findings suggest that mentoring and induction support in the United States are continually progressing to conform to the dynamic trends in education and organizational management, which is evident in the diversification of their forms and types. American educators and policymakers extensively use new forms of mentoring, such as online mentoring, group mentoring, reciprocal mentoring, needs-driven mentoring etc. The analysis of induction and mentoring programs, district professional development plans and other documentation, carried out in the process of research, reveals their core components, goals and the peculiarities of their design and implementation. Special attention is given to mentor training, selection and matching. Novice teacher support is viewed as an effective instrument which allows school districts to reduce teacher turnover, improve student achievement by providing students with quality instruction and promote collaboration within teaching staff and administration.

Key words: mentoring, beginning/novice teacher, mentor, protégé, new teacher induction, induction program, professional development, in-service training.

\section{INTRODUCTION}

Education policies of the USA and other economically developed countries are focused on raising the quality of education and equipping every learner with twenty-first century knowledge and skills. Fostering quality teaching is vital for the improvement of education at the school level. Beginning teachers are expected to perform on the level of veteran teachers, which often poses severe challenges to inexperienced novices and influences their decision to leave the teaching profession. American researchers admit that since preservice teacher training is mostly theoretical in nature, beginning teacher's expertise falls short of what is required by modern school and is not sufficient to address the needs of students and the local community. At the same time, the first year of teaching is a stressful period in any teacher's career, during which organizational socialization and professional adaptation occur, i.e. assuming roles and responsibilities, adjusting to school climate, culture and values, learning to collaborate. During this initial stage of professional development, novice teachers need special attention and ongoing support from school administration, teaching staff and local education agencies. Such system of social, psychological and instructional support, with mentoring being its core component, has been successfully operating in the USA during the last three decades.
\end{abstract}




\section{THE AIM OF THE STUDY}

The aim of the study is to analyze the American experience of supporting novice teachers through mentoring and induction during the first 1-3 years of teaching and highlight the effective strategies and policies which could be implemented to support beginning teachers in Ukrainian schools.

\section{THEORETICAL FRAMEWORK AND RESEARCH METHODS}

Ever since the educational reforms of 1980 s were initiated, the problems of teacher quality and quantity have been extensively discussed in American literature. Mentoring as a method of in-service teacher training and support and a core component of induction programs for beginning teachers in the United States has been researched by T. Bey, L. Darling-Hammond, S. Feiman-Nemser, J. Fluckiger, M. Fullan, C. Galvez-Hjornevik, T. Ganser, A. Hargreaves, D. Haselkorn, L. Huling-Austin, R. Ingersoll, M. Jacobi, K. Kram, J. Little, D. Lortie, S. Merriam, E. Moir, S. Odell, H. Portner, R. Stanulis, L. Tillman,S. Veenman, H. K. Wong and others. The findings of the current study were obtained using such research methods as comparative analysis, content analysis, systematization and theoretical summarization.

\section{RESULTS}

Theoretical analysis gives sufficient evidence to conclude that American researchers have not reached consensus on the definition of mentoring in teaching. However, synthesizing a number of interpretations of the term, we were able to define teacher mentoring as a mutually beneficial formal collaboration between an experienced teacher (mentor) and a beginning teacher (mentee/protégé) which provides the new professional with ongoing psychosocial and instruction-related support during the first 1-3 years of teaching. The major goals of new teacher mentoring are: to provide guidance and support, to increase retention, and to promote professional development. Broadly defined, mentoring is a process which facilitates adaptation of novice teachers to real working conditions, increases their motivation, positive attitude to teaching profession and psychological comfort, promotes effective interpersonal communication and collaboration with teaching staff and administration. In its narrow meaning, mentoring is viewed as a method for sharing specific knowledge, skills and strategies with their modeling and guided implementation in novice's teaching practice.

Teacher mentoring in the U.S. education system usually refers to in-service assistance and support of beginning teachers with 0-3 years of experience, but it may also imply: a) practical pre-service training of prospective teachers (student teaching); b) counseling and guiding the socialization of teachers who arrived from another state or school district even though they already have some teaching experience; c) supporting teachers who are getting back to work after a long break (more than 3 years).

Mentors in the United States are experienced, motivated and highly qualified teacher leaders, usually certified by the National Board for Professional Teaching Standards (NBPTS). A common practice in school districts having a shortage of experienced teachers is getting motivated retired teachers to serve as mentors. So far as average teacher retirement age is 59 (Carroll \& Foster, 2008), many retired teachers still have enough energy and enthusiasm to continue working. A lot of them consider supporting beginners to be a way of their professional self-actualization. According to the survey carried out by the National Commission on Teaching and America's Future (NCTAF), almost $60 \%$ of preretirement age teachers said they intended to work after retirement. They survey found that $70 \%$ of the teachers nearing retirement would be interested in staying if they were able to work in new education roles (Carroll \& Foster, 2008). 
Since serving as a mentor is voluntary, most school districts offer some incentives to encourage mentors, such as: a) reduced workload (released time for frequent meetings with their protégés); b) stipends or salary supplements (an average of $\$ 1,000$ to $\$ 1,500$ for each mentee annually, plus compensation of travel expenses); c) advanced career opportunities; d) presents, certificates, awards, end-of-year and graduation ceremonies in recognition of mentor's contribution. According to J. Ballinger, mentors must be given enough released time to work with beginning teachers, because "the mentor relationship is too important to be squeezed into the margins of an already busy workday" (Ballinger, 2000). Mentors are released full-time if they work with a group of beginning teachers or several individuals.

The analysis of school district policies, state policies and guidelines to teacher mentoring programs across the states shows that the following criteria must be met for candidates to be selected as teacher mentors: a) formal requirements: 1) a minimum of 5 years of full-time teaching experience (in the majority of states, except those requiring teachers to have at least 3 consecutive years of successful teaching experience, such as Alabama, Arizona, Connecticut, Kansas, New Jersey, Florida, Virginia etc. and two states where prospective mentors with at least 10 years of classroom experience are eligible: Louisiana and North Carolina); 2) a valid teaching credential; 3) high level of teaching expertise, professional commitment and leadership skills; b) personal characteristics and skills: 1) willingness to be a mentor and serve as a role model; 2) excellent reputation; 3) ability to demonstrate empathy, enthusiasm, encouragement, selflessness and confidentiality; 3) ability to work with adult individuals, being aware of their cognitive styles and peculiarities of adult learning; 4) reflective thinking, listening and observation skills; 5) desire to continuously learn and promote self-improvement; 6) being ready to accept the time commitment involved in mentoring a novice teacher; 7) an ability to provide constructive and corrective feedback to the beginning teacher. It is important to note that selecting mentors with 3 years of teaching experience is inconsistent with the studies (Moore Johnson, 2006), (Berliner, 2004) proving that it takes at least 5 years for teachers to become confident and skilled professionals and teachers with fewer than 5 years of experience should still be regarded as novices.

A number of states (Arkansas, Delaware, Montana, etc.) have implemented rigorous mentor selection procedure which includes having a track record of positive effect on student achievement and showing evidence of ongoing professional growth, often documented at the district level in accordance with Consolidated School Improvement Plan. Mentor training prior to the program is required in 31 states. In 15 states it is followed by on-going professional development for mentors (Goldrick et al., 2012). Mentor selection and matching in the reviewed states is carried out by principals, site coordinators, program facilitators and lead mentors.

Basic criteria for matching mentors and mentees include: close proximity to the novice teacher, preferably the same building (except online mentoring, when physical presence is not needed); certification in the same area; common grade level. As for the optimal age difference between mentor and novice teacher, literature suggests that it should be $8-15$ years. Greater age difference (20 years or more) is not recommended, because it may cause misunderstandings in their relationship as a result of generation gap.

Some of the previously stated requirements and criteria are applicable to the traditional one-on-one mentoring model only, wherein mentoring support of a novice teacher is provided by an older, highly qualified and experienced professional. Meanwhile, the current trends in education and present day socioeconomic realities contribute to the evolution of mentoring, diversification of its forms and types. On the basis of the reviewed 
professional literature, school district policies and documents, etc., we were able to classify teacher mentoring in the USA according to the following criteria: a) number of participants: one-on-one mentoring (individual mentoring), group mentoring and team mentoring; b) regulation of mentor-protégé relationship, their accountability: formal and informal mentoring; c) level at which mentoring program is realized: school-based mentoring, district-based mentoring; d) type of mentor-protégé interaction: face-to-face mentoring (inperson mentoring), online mentoring (also called e-mentoring/telementoring/web-based mentoring); e) vector of developmental action: peer mentoring, reciprocal mentoring, reverse mentoring; f) duration of mentoring program: situational mentoring, ongoing mentoring (mentoring throughout induction), needs-driven mentoring.

Having studied a number of mentoring program plans, we may identify their basic components: the aim of mentoring program, expected outcomes, target group, duration, requirements for participation, mentor selection and matching criteria, benefits for the participants and the organization, funding, types of materials and resources available for mentors, mentees and facilitators, planned activities and events. Among planned activities and events, special attention should be devoted to classroom observation and formative assessment. Researchers S. M. Kardos and E. Liu (Kardos \& Liu, 2003) found that 43\% of U.S. teachers go through their entire first year of teaching without being observed by a mentor or a more experienced teacher.

The professional literature overwhelmingly points to the benefits of mentoring as a powerful, cost-effective and time-tested tool which can significantly reduce new teacher turnover (which includes attrition and migration), particularly when combined with other components of induction programs, such as reflective teaching practices, formative assessment, networking, administrative support, job-embedded professional development. It should be mentioned that although the terms "mentoring program" and "induction program" are generally used in the same context, there's a tangible disparity in the amount of support they provide. While mentoring is usually a component of a more intensive induction program, it can also be used as a self-sufficient method of instructional and psychosocial support of new teachers. However, the function of addressing diverse personal (emotional support and encouragement), professional (understanding of school and district policies, procedures and priorities) and instructional needs (classroom management, student assessment, lesson planning, curriculum content and methodology) of beginning teachers is more frequently attributed to comprehensive induction programs. Realization of a comprehensive induction program is a well-planned, sustained and structured process which involves a variety of activities, events and participants offering multifaceted support and assistance to beginning teachers during their first 2-3 years at school. Typically, comprehensive induction programs in the USA are partnerships of school districts and universities. Sometimes school districts, universities and local educational agencies consolidate into special consortia, such as the Sacramento Beginning Teacher Support and Assessment Consortium - a strong partnership of 17 school districts and California State University which addresses teacher needs in the preservice year and in the first two years of teaching (Scherer et al., 1999). Partnership with local school districts allows the university to assess the competency of their graduates, get the feedback essential for improving their teacher training programs and making them more adapted to the needs of the districts.

Mentoring and induction support were brought to the forefront of American educational discourse in 1980s, when the forthcoming dramatic loss of teacher force became apparent. During the late 1960s through early 1980s American schools were flooded with teachers born during the post-World War II baby boom (between 1946 and 
1964). In 1994, Richard W. Riley, former U. S. Secretary of Education, warned that American schools would need to hire 2 million teachers within 10 years to close the breach that would emerge after mass retirements of baby boomers. Over the next decade 2,25 million teachers were hired. But during the same decade the nation lost 2,7 million teachers, with more than 2,1 million of them leaving before retirement (Carroll, 2007). Along with the mass retirement, the rate of teacher turnover began to increase annually since 1994. In 2008 NCTAF estimated that over $30 \%$ of new teachers were leaving the profession within 3 years of teaching (Carroll \& Foster, 2008). The annual attrition rate for first-year teachers has increased by over $40 \%$ in the past two decades (NCTAF, 2014). Current turnover rate among beginning public school teachers remains rather high, with about $13 \%$ movers and 7\% leavers in school year 2012-13 (Goldring et al., 2014).

Existing research abounds with empirical data demonstrating the destructive influence of continued teacher turnover on student achievement and school climate. At the school level, teacher attrition and mobility cause the destabilization of the learning environment which manifests itself in the disruption of instructional continuity, disintegration of teaching staff, increased bureaucratization and standardization which restrict creativity, reduced teacher collegiality and collaboration, psychological discomfort of students as a result of frequently changing teachers, low student achievement (clearly evident in unsatisfactory PISA and SAT results of U.S. schoolchildren in 2012 and 2013) because of poorly organized instruction by inexperienced or underqualified teachers, and excessive workload of substitute teachers. At the district level, teacher turnover leads to reduced access of students to quality education, particularly in urban hard-to-staff public schools serving low-income, underachieving and minority students; inability of school districts to fill the vacancies in particular subjects and fields, such as science, math, foreign languages and special education; considerable time expenses and financial resources needed to constantly recruit and train new teachers. According to NCTAF, the annual cost of teacher turnover for U.S. school districts is $\$ 7,2$ billion (Carroll, 2007). The cost per teacher-leaver ranges from $\$ 4,366$ in a small rural district, such as Jemez Valley, New Mexico, to $\$ 17,872$ per teacher-leaver in a large district, such as Chicago Public Schools (Barnes et al., 2007).

Implementation of induction programs was part of U.S. educational reforms of 1980s. As opposed to alternative certification and standardization reform which both received a fair amount of criticism from American researchers, teacher induction support was viewed as the most promising way to solve the problems of teacher quality and quantity. These reforms were followed by a number of governmental initiatives which were launched to increase teacher recruitment and retention, such as raising teacher salaries, providing better working conditions (strong administrative support, class size reduction, greater resources for teaching, teacher input into the decision-making process), improvement of preservice teacher training, and further intensification of new teacher induction and mentoring support.

The use of mentoring as a self-sufficient instrument to retain new teachers has been a subject of frequent contention over the last decade. Some researchers (H. K. Wong, L. Darling-Hammond, R. Ingersoll and others) claim that only comprehensive, coherent and sustained system of professional support and training for new teachers, such as formal induction program, can fully address their needs and increase new teachers' quantity and quality. H. K. Wong suggests that schools shouldn't rely on one-to-one mentoring and, instead, develop schoolwide structures that promote integrated professional cultures with frequent exchange of information and ideas across experience levels (Wong, 2013). 
On the other hand, the literature provides numerous examples of successfully implemented mentoring programs which reduced teacher turnover, improved teaching ability and increased job satisfaction among beginning teachers. The U.S. National Center for Education Statistics found that among the beginning public school teachers who didn't participate in a mentoring program in 2007-2008, about $16 \%$ left their profession in 20082009 and 23\% were not teaching in 2009-2010. In contrast, among the beginning public school teachers who were provided with mentoring support in 2007-2008, about $8 \%$ were not teaching in 2008-2009 and 10\% were not teaching in 2009-2010 (Kaiser \& Cross, 2011).

According to the New Teacher Center report (Goldrick et al., 2012), 27 states currently require school districts to run an induction or mentoring program for every new teacher. In 14 states all new teachers are required to participate in a state-funded induction program, and in 16 states participation in a state-funded mentoring program is required (NCES, 2012). Since U.S. education system is decentralized, the content, duration, and funding of induction programs vary greatly among the states and school districts. The intensity of induction support may range from a formal orientation session prior to the start of the school year to a comprehensive, sustained and coherent support program with multiple components and extensive professional development opportunities for beginning teachers, such as mentoring, administrative support, observation, counseling, formative assessment and standards-based evaluations, teacher collaboration (including peer support groups, peer coaching/learning, access to an external teacher network), seminars, webinars, conferences, development of professional portfolio. Mentoring and other forms of teacher support are usually regulated by District Professional Development Plan.

\section{CONCLUSIONS}

Our results add to the extant body of research on mentoring by highlighting the organizational and design-related aspects of new teacher mentoring and induction in the United States. Supporting and training American novice teachers are challenging tasks for mentors because of heterogeneous system of teacher certification/licensure and pre-service training, as well as diverse standards across the states. A remarkable feature of U.S. new teacher mentoring and induction is collaborative approach to their design and implementation: universities and local educational agencies are often involved. Programs are tailored to the needs of the parties concerned (the beginning teacher, mentor, school and school district) and the resources available in a particular school. Implementing these and some other ideas (comprehensive induction, rigorous mentor selection and matching, formative assessment, mentor training, reduced workload and administrative support, innovative forms of mentoring) could improve the professional support of beginning teachers in Ukraine. Additional inquiry is needed to develop an instrument for evaluating the effectiveness of mentor-mentee interaction. Research would also benefit from analyzing the cases of dysfunctional mentoring relationships and discovering ways to stimulate motivation of veteran teachers for mentoring.

\section{REFERENCES}

1. Ballinger, J. (2000). Programs aim to stop teacher washout. JSD, National Staff Development Council, p. 28-33. Retrieved 20.02.2015 from: http://learningforward.org/docs/jsd-spring-2000/ballinger212.pdf?sfvrsn=2.

2. Barnes, G., Crowe, E., \& Schaefer, B. (2007). The Cost of Teacher Turnover in Five School Districts. National Commission on Teaching and America's Future, 
Washington DC, p. 97 Retrieved 21.02.2015 from: http://files.eric.ed.gov/fulltext/ED4971 76.pdf.

3. Berliner, D.C. (2004). Describing the behavior and documenting the accomplishments of expert teachers. Bulletin of Science, Technology \& Society, Vol. 24, No 3, p. 200-212.

4. Carroll, T. G. (2007). Policy Brief. The High Cost of Teacher Turnover. National Commission on Teaching and America's Future, Washington D.C., p. 13 Retrieved 19.02.2015 from: http://nctaf.org/wp-content/uploads/2012/01/NCTAF-Cost-ofTeacher-Turnover-2007-policy-brief.pdf

5. Carroll, T. G., Foster, E. (2008). Learning Teams: Creating What's Next. National Commission on Teaching and America's Future, p. 20 Retrieved 20.02.2015 from : http://nctaf.org/wp content/uploads/2012/01/NCTAFLearningTeams408REG2.pdf.

6. Goldrick, L., Osta, D., Barlin, D, \& Burn, J. (2012). Review of State Policies on Teacher Induction. Santa Cruz, California: New Teacher Center, p. 38.

7. Goldring, R., Taie, S., \& Riddles, M. (2014). Teacher Attrition and Mobility: Results From the 2012-13 Teacher Follow-up Survey. U.S. Department of Education. Washington, DC: National Center for Education Statistics. Retrieved 21.02.2015 from : http://nces.ed.gov/pubs2014/2014077.pdf.

8. Kardos, S.M. \& Liu, E. (2003). New Research Finds School Hiring and Support Practices Fall Short. Retrieved 21.02.2015 from: http://www.gse.harvard.edu/news/03/04/new-research-finds-school-hiring-and-supportpractices-fall-short.

9. Moore Johnson, S. (2006). The Workplace Matters. Teacher Quality, Retention and Effectiveness. National Education Association, p. 27. Retrieved 19.02.2015 from : http://files.eric.ed.gov/fulltext/ED495822.pdf.

10. Kaiser, A., Cross, F. (2011). Beginning Teacher Attrition and Mobility: Results from the First Through Third Waves of the 2007-08 Beginning Teacher Longitudinal Study. National Center for Education Statistics. Retrieved 21.02.2015 from : http://nces.ed.gov/pubs2011/2011318.pdf.

11. National Center for Education Statistics. (2012). Requirements for participation in state-funded induction programs and mentoring programs for beginning teachers [...]. Retrieved 19.02.2015 from : http://nces.ed.gov/programs/statereform/tab3 7.asp.

12. National Commission on Teaching and America's Future. (2014). It's Time to Solve the Teacher Turnover Problem. Retrieved 20.02.2015 from : http://nctaf.org/featuredhome/teacher-turnover-a-chronic-problem.

13. Scherer, M. (Ed.). (1999). A Better Beginning. Supporting and Mentoring New Teachers. Alexandria, Virginia: Association for Supervision and Curriculum Development, p. 246.

14. Wong, H. K. (2013). Significant Research and Readings on Comprehensive Induction. Retrieved 19.02.2015 from : http://www.newteacher.com/pdf/Significant_Resear ch_on_Induction.pdf. 